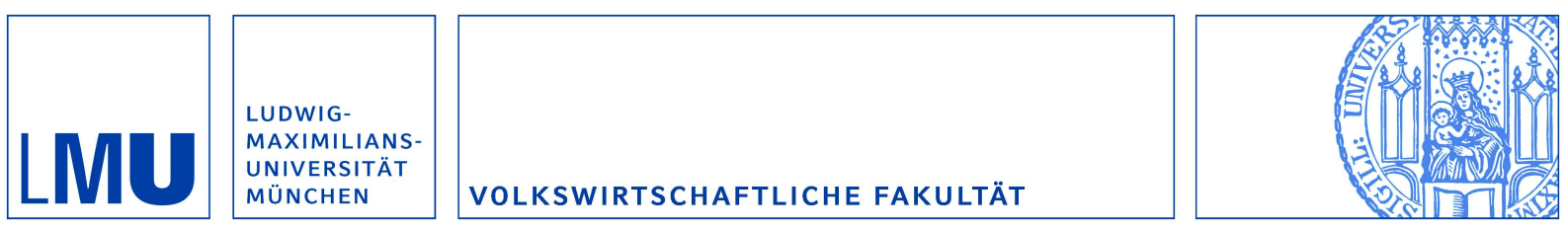

Salamon, Peter und Komlos, John:

The Poverty of Growth with Interdependent Utility Functions

Munich Discussion Paper No. 2005-9

Department of Economics

University of Munich

Volkswirtschaftliche Fakultät

Ludwig-Maximilians-Universität München

Online at https://doi.org/10.5282/ubm/epub.619 


\section{The Poverty of Growth with Interdependent Utility Functions}

John Komlos, Department of Economics, University of Munich and

Peter Salamon, Department of Mathematics, San Diego State University

In this essay we explore the implications of economic growth for welfare in the presence of interdependent utility functions with negative externalities in consumption, i.e. envy. In conventional theory, the utility function of a "typical" economic agent is generally assumed to be independent of the consumption of others; hence more consumption invariably "...leads to more happiness" not only of the individual, but in the aggregate as well. According to the common wisdom, economic growth leads invariably to an increase in welfare (Layard and Walter, 1978, p. 5). Yet, experimental evidence refutes the notion that people invariably feel better off with increased consumption (Easterlin, 1974; Abramovitz, 1979; p. 9). ${ }^{1}$

Our paper assumes that "...the individual does not think and act in the same way irrespective of whether he is or is not a member of a group" (Weisskopf, 1971, p. 161; Katona, 1975, p. 49; Leibenstein, 1950: Frank 1985; McCracken, 1988, p. xi; Konrad, 1990). "Reference groups" are important for providing standards for the subjective evaluation of one's own well-being, and in formulating expectations and aspirations on which satisfaction frequently depends. ${ }^{2}$ Thus, "...people's standards of wealth are determined by comparisons with kin, peers, etc., and thus if they all rise together [over time] the relative difference disappears, and so as people get wealthier over time they do not become any more happy" (Furnham and Lewis, 1986, p. 109).

This skepticism toward the received wisdom is shared by an increasing number of researchers (Sen, 1977; Hammond, 1989; Konrad, 1992a), but interdependent utility functions have been formulated ever since the publication of 
Veblen's seminal theory of conspicuous consumption³ (1899; Mishan, 1961; Frank, March 1985; Bagwell and Bernheim, 1996; Postlewaite, 1998). Duesenberry "...specifie[d] utility of an individual as a function of his own income and that of the income of the other members of the society"4 (Duesenberry, 1949, p. 97). Admittedly, consumption can also have positive externalities: for example, a wife's utility can enter the utility function of her spouse altruistically (Becker, 1981).

Empirical and theoretical investigations of the social nature of utility functions are important for several reasons: the "neglect of interdependence of welfare functions may substantially bias policy conclusions" (Kapteyn and Herwaarden, 1980, p. 395); it also has major implications for progressive taxation (Feldstein, 1976, p. 81; $\mathrm{Ng}, 1987)$, for income redistribution, for the formulation of growth policy, as well as for the justification of the existence of the welfare state in general (Freshtman, Murphy, Weiss, 1966; Hammond, 1991). ${ }^{5}$ We proceed in this vein, and explore some implications of economic growth for welfare in the presence of interdependent utility functions following Feldstein's formulation. ${ }^{6}$ We demonstrate that, contrary to standard theory, growth need not raise aggregate welfare, if its benefits accrue unevenly, and if the utility functions of the population are interdependent (Konrad, 1992b).

\section{The Model}

We begin with a model in which the society is assumed to be composed of two individuals $A$ and $B$ with interdependent Cobb-Douglas utility functions with one good, $x$, (i.e., income). ${ }^{7}$

1)

$$
U_{A}=\left(x_{A}^{\alpha}\right) /\left(x_{B}^{\beta a}\right) ; \quad U_{B}=\left(x_{B}^{\alpha}\right) /\left(x_{A}^{\beta}{ }^{\alpha}\right)
$$

The social welfare function is assumed to be additive and democratic:

2) $\quad U_{T}=U_{A}+U_{B}$. 
Suppose that national income increases exogenously, e.g. through the discovery of new resources. Assume, that the increment in $\mathrm{x}$ accrues only to $\mathrm{A}$. The question is under what circumstances, if any, might economic growth lead to a decline in total welfare, contrary to standard analysis (McAdams, 1992).

Noting that

$$
\partial U_{T} / \partial x_{A}=\alpha_{a} U_{A} / x_{A}-\beta_{b} U_{B} / x_{A}
$$

we obtain that the aggregate utility of the society decreases if and only if 4) $\quad U_{A} / U_{B}<\beta_{b} / \alpha_{a}$.

The outcome depends on the relative magnitudes of the terms on the two sides of this inequality. The right hand side is an index of the degree of interdependence of the utility functions, while the left hand side measures the inequality in the initial distribution of utility. The initial income distribution determines $U_{A} / U_{B}$, and hence whether it is smaller than $\beta_{b} / \alpha_{a}$. The stronger is the interdependence, i.e. the larger is the value of $\beta_{b} / \alpha_{a}$, the larger is the range of utility values for which inequality (4) holds.

The ratio $\beta_{b} / \alpha_{a}$ indicates the extent to which the consumption of $x$ by $A$ decreases B's utility as compared with the extent that it increases A's own utility. The size of the ratio is indicative of the degree to which members of society may be characterized as "envious" ( $\beta$ ) relative to being self-contained $(\alpha)$. The larger is the ratio, the stronger is the interdependence. Without interdependence $\beta=0$ and the ratio on the right hand side is zero, making it impossible for inequality (4) to ever hold, since the left hand side is always positive. In an altruistic society $\beta<0$, and again the inequality becomes impossible. Consequently, in these two cases we have the standard conclusion that growth always increases total welfare. If $\beta>0$, however, the inequality can hold provided the ratio of utility levels is less than $\beta_{b} / \alpha_{a}$. 
The case $\beta_{b} / \alpha_{a}>1$ corresponds to the unrealistic case of a society in which enviousness dominates over self-centeredness. ${ }^{8}$ Hence, we assume that $0<\beta_{b} / \alpha_{a}<$ 1.

In this parameter range, growth can lead to a diminution in total social welfare in the two person case provided the gain accrues to the individual whose utility is initially lower by a sufficient ratio. This result becomes understandable by noting that in this model a part of the utility of the "wealthier" person, $B$, is derived from his relative wealth. If he is sufficiently envious, his utility can decrease more than the increase in A's utility. ${ }^{9}$

The main conclusion from the above example is that there exists a region of parameter space where an exogenous increase in income which changes the distribution of income, decreases total welfare in a democratic aggregate utility function. One should note that this conclusion is dependent on the assumed form of the utility function. In particular, if we repeat the analysis with $U^{\prime}=\ln U$, where $U$ is as in eq. 1., the conclusion changes and welfare increases in response to growth with any income distribution provided only that $\beta_{b}<\alpha_{a}$, as expected. On the other hand, replacing the Cobb-Douglas utility functions (eq. 1) with Stone-Geary, or, in fact, with separable utility functions of the form

$$
\mathrm{U}_{\mathrm{A}}=\widehat{\mathrm{U}_{\mathrm{A}}} /{\widehat{\mathrm{U}_{\mathrm{B}}}}^{\delta_{\mathrm{a}}} ; \quad \mathrm{U}_{\mathrm{B}}=\widehat{\mathrm{U}_{\mathrm{B}}} / \widehat{\mathrm{U}_{\mathrm{A}}} \delta_{\mathrm{b}} .
$$

where $\widehat{U}$ indicates the utility of a consumer at some fixed level of utility for the other consumer, ${ }^{10}$ we obtain that total welfare can decrease provided ${ }^{11}$

$$
\mathrm{U}_{\mathrm{A}} / \mathrm{U}_{\mathrm{B}}<\delta \mathrm{b} \text {. }
$$

The parameter $\delta b$ now plays the role of $\beta_{b} / \alpha_{a}$. 


\section{Conclusion}

The above model explores the welfare implications of economic growth in a society composed of individuals with interdependent utility functions with negative externalities in consumption. We demonstrate that there do exist specifications of utility functions with regions of parameter space in which the welfare consequences of a rise in per-capita income are ambiguous, if the gains are distributed unequally. Hence, economic growth might bring about an increase as well as a decrease in aggregate social welfare depending on the relationship between the two indices in eq 4. One index measures the extent of envy in the society and the other the degree of income inequality as measured by the initial ratio of utilities. Total welfare is more likely to decrease if the gains from growth accrue disproportionately to the individual with the lower level of utility, the more envious is the individual who does not benefit from growth, the less selfish is the individual who gains from growth, and the more unequally income is distributed initially. ${ }^{12}$

These considerations are important, insofar as economic growth has been frequently associated with the skewing of the income distribution in favor of the upper income brackets. In an historical context, Simon Kuznets recognized this pattern for the early phases of modern economic growth (Kuznets, 1996, p. 212; Williamson and Lindert, 1980, pp. 62, 67; Lindert, 1991, p,. 216; Williamson, 1985, p. 18; Williamson, 1991, p. 15), ${ }^{13}$ and recent evidence confirms the increase in the Gini coefficient in Eastern Europe and the successor states of the Soviet Union during the recent transition to a market economy (Milanovic, 1996, p. 133). In many of these countries the Gini coefficient increased from 0.25 to 0.30 in just five years (United Nations Development, 1993, p. 17). In the United Kingdom a 2.1 percent growth rate in per capita GNP between 1965 and 1993 has been accompanied by a rise in the gini 
coeffienient from 0.25 to 0.32 . (The World Bank, 1993). In most countries of the world a wide divide separates the poor from the rich. In the United States, for instance, the richest 20 percent of the population earns 9 times as much as the poorest 20 percent. ${ }^{14}$ Hence, insofar as the benefits of economic growth often accrue unevenly, our theoretical considerations have practical policy implications.

Clearly, we analyzed a special case, and therefore, the result ought not be assumed to pertain generally. Nonetheless, our derivation does have far-reaching policy implications. One issue to explore is the extent to which the utility function of economic agents are interdependent. We have demonstrated that with gains of economic growth accruing unevenly, circumstances do exist such that a society could be better off either by choosing to forgo the opportunities for growth, or by government policy affecting the distribution of gains. Thus, there is room for government intervention. The reason for the existence of the welfare state is not only the amelioration of market failure, or the provision of comprehensive security, but also because of the existence of externalities in consumption - envy - imply that individual utility maximization does not automatically bring about utility maximization for the society. The society could be not only happier, but also more stable politically, with a more even distribution of the gains from growth, and a diminution in envy (Hammond, 1995). Our conclusion vividly redirects our focus from growth per se to its distributional consequences for aggregate welfare. ${ }^{15}$ In sum, the interdependent nature of a society's utility function should not be neglected in the formulation economic policy, particularly with regard to such key issues as progressive taxation, redistribution of income, and the enactment of growth-inducing policy measures. ${ }^{16}$ 


\section{References}

Abramovitz, Moses. "Economic Growth and Its Discontents," in Michael J. Boskin (ed.), Economics and Human Welfare. Essays in Honor of Tibor Scitovsky (New York: Academic Press, 1979), pp. 3-22.

Bagwell, Laurie S. and B. Douglas Bernheim, "Veblen Effects in a Theory of Conspicuous Consumption," American Economic Review 86(3):349-373, June 1996.

Basmann, Robert L., Molina, David J., and Daniel J. Slottje, 1983 "Budget Constraint Prices as Preference Changing Parameters of Generalized FechnerThurstone Direct Utility Functions," American Economic Review 73:411-413.

Basmann, Robert L., Molina, David J., and Daniel J. Slottje, "A Note on Measuring Veblen's Theory of Conspicuous Consumption," Review of Economics and Statistics 70:531-535, 1988.

Becker, Gary S. "Altruism in the Family and Selfishness in the Market Place," Economica, new ser, 48:1-15, 1981.

Cole, Harold L, Maliath George J., and Postelwaite, Andrew. "Social Norms, Saving Behavior, and Growth." Journal of Political Economy, 100 (6): 1092-125, Dec. 1992.

Duesenberry, James S., Income, Saving, and the Theory of Consumer Behavior. New York: Oxford Univ. Press, 1967; first published in 1949.

Easterlin, R. A., "Does Economic Growth Improve the Human Lot? in P. A. David and M. W. Reder (eds.), Nations and Households in Economic Growth (New York: Academic Press, 1974), pp. 89-125.

Feldstein, Martin, "On the Theory of Tax Reform." Journal of Public Economics 6:77-104, 1976.

Fershtman, Chaim, Murphy, Kevin M., and Yoram Weiss, "Social Status, Education, and Growth," Journal of Political Economy 104:108-132, 1996. 
Fisher, Franklin M., "On Donor Sovereignty and United Charities." American Economic Review 67:632-638, 1977.

Frank, Robert H., "If Homo Economicus Could Choose His Own Utility Function. Would He Want One with a Conscience?" American Economic Review 77 (Sept. 1987) 4, pp. 593-604.

Frank, Robert H., Choosing the Right Pond. Human Behavior and the Quest for Status. New York: Oxford Univ. Press, 1985.

Frank, Robert H., "Demand for Unobservable and Other Nonpositional Goods," American Economic Review 75 (March 1985), pp. 101-16.

Frank, Robert H., "Interdependent Preferences and the Competitive Wage Structure." Rand Journal of Economics 15:510-520, 1984.

Furnham, Adrian, and Lewis, Alan, The Economic Mind. The Social Psychology of Economic Behavior. New York: St Martins Press, 1986.

Haavelmo, Trygve, "Some Observations on Welfare and Economic Growth." in W. A. Eltis, M. FG. Scott, and J. N Wolfe (eds.), Induction, Growth and Trade: Essays in Honour of Sir Roy Harrod. Oxford: Clarendon Press, 1970, pp. 65-75. Hammond, Peter, J., "Altruism," in Stefano Zamagni, (ed.), The economics of altruism. Elgar Reference Collection. International Library of Critical Writings in Economics, vol. 48. Aldershot, U.K., 1995, pp. 165-67.

Hammond, Peter, J., "Interpersonal Comparisons of Utility: Why and How They Are and Should Be Made," in Jon Elster and John E. Roemer (eds.), Interpersonal comparisons of well-being. Studies in Rationality and Social Change. Cambridge; New York and Melbourne: Cambridge University Press in collaboration with Maison des Sciences de l'Homme, 1991, pp. 200-254.

Hammond, Peter, J., "Some Assumptions of Contemporary Neoclassical Economic Theology," in Geore R. Feiwel, (ed.), Joan Robinson and modern 
economic theory. New York: New York University Press; distributed by Columbia University Press, 1989, pp. 186-257.

Konrad, Kai, and Lommerud Kjell Erik, "Relative standing comparisons, risk taking, and safety regulations," Journal of Public Economics 48, 1992a.

Kapteyn, Arie, and Van Herwaarden, Floor G., "Interdependent Welfare Functions and Optimal Income Distribution," Journal of Public Economics 14:375397, 1980.

Katona, George, Psycologyical Economics. New York: Elsevier Scientific Publishing Co., Inc., 1975.

Konrad, Kai, "Wealth Seeking reconsidered," Journal of Economic Behavior and Organization 18: 215-227, $1992 \mathrm{~b}$.

Konrad, Kai, "Statuspräferenzen: Soziobiologische Ursachen, Statuswettrüsten und seine Besteuerung," Kyklos 43: 249-70, 1990.

Kuznets, Simon. Modern Economic Growth: Rate, Structure, and Spread. New Haven: Yale University Press, 1966.

Layard, P.R.G., and Walters, A.A., Microeconomic Theory. New York: McGraw Hill Book C., 1978.

Leibenstein, Harvey, "Bandwagon, Snob, and Veblen Effects in the Theory of Consumers' Demand," Quarterly Journal of Economics, 64(2):183-207, May, 1950. Lindert, Peter. "Toward a Comparative History of Income and Wealth Inequality." In Income Distribution in Historical Perspective, edited by Y. S. Brenner, Hartmut Kaelble, and Mark Thomas, 212-231. Cambridge: Cambridge University Press, 1991. McAdams, Richard H., "Relative Preferences," The Yale Law Review, 102:1$104,1992$. 
McCracken, Grant, Culture and Consumption. New Approaches to the

Symbolic Character of Consumer Goods and Activities. Bloomington: Indiana Univ. Press, 1988.

Milanovic, Branko. "Income, Inequality and Poverty during the Transition: A Survey of the Evidence." MOCT-MOST Economic Policy in Transitional Economies 6, no. 1 (1996): 131-147.

Mishan, E.J., "Theories of Consumer's Behaviour: A Cynical View," Economica, new ser., 27:1-11, 1961.

$\mathrm{Ng}$, Yew-Kwang, "Diamonds are a Government"s Best Friend: Burden-Free Taxes on Goods Valued for their Values." American Economic Review 77(1):186-91, March 1987.

Postlewaite, Andrew, "The social basis of interdependent preferences," European Economic Review, 42 (1998): 779-800.

Scitovsky, Tibor, The Joyless Economy. New York: Oxford University Press, 1976

Sen, Amartya, "Rational Fools: A Critique of the Behavioral Foundations of Economic Theory." Philosophy and Public Affairs 6:317-344, 1977.

Spiegel, Uriel, and Templeman Joseph, "Interdependent Utility and Cooperative Behavior." Journal of Comparative Economics 9:314- 328, 1985.

United Nations Development Programme, Human Development Report 1993 (New York: Oxford University Press, 1993).

Veblen, Thorstein, The Theory of the Leisure Class. New York: McMillan, 1899.

Weiermair, Klaus, and Perlman, Mark (eds.), Studies in Economic Rationality: X-efficiency Examined and Extolled: Essays Written in the Tradition of and to Honor Harvey Leibenstein. Ann Arbor: University of Michigan Press, 1990. 
Weisskopf, Walter A., Alienation and Economics. New York: E.P. Dutton and Co., Inc., 1971.

Williamson, Jeffrey. Did British Capitalism Breed Inequality?. London: Allen \& Unwin, 1985.

Williamson, Jeffrey. Inequality, Poverty, and History. The Kuznets Memorial Lectures of the Economic Growth Center, Yale University. Oxford: Basil Blackwell, 1991.

Williamson, Jeffrey and Peter Lindert. American Inequality: A Macroeconomic History New York: Academic Press, 1980.

The World Bank, World Development Report 1993. Investing in Health (New York: Oxford University Press, 1993).

Footnotes 
${ }^{1}$ Admittedly, in the short run "...one might feel happier by a recent increase in the standard of living, [but] one soon adapts to this and the positive relationship disappears." Hence, over time "...no strong positive relationship [has been found] either cross-sectionally or longitudinally between money [income] and happiness" (Furnham and Lewis, 1986, p. 109). We are not substantially happier than our ancestors even though we consume much more than they did (Scitovsky, 1976).

${ }^{2}$ As Duesenberry pointed out a generation ago, "the utility derived from one's own house or car depends on a friend's house or car" (1949, p. 27).

${ }^{3}$ Its main insight fits well the post-World War II U.S. private consumption experience (Bassman, Molina, and Slottje, 1988).

${ }^{4}$ Furthermore, the price of the consumed good can be included in the utility function, thus generating a "snob appeal" effect (Basmann, Molina, and Slottje, 1983; Haavelmo, 1970; Fisher, 1977; Spiegel and Templeman, 1985; Frank 1987).

${ }^{5}$ For instance, Spiegel and Templeman have shown "...that a 'compulsory bundle' which a group... accepts as binding upon all its members might be superior to any other consumption pattern from the point of view of each and every member of the group" (1985, p. 315). Moreover, employees care about relative income within a firm, not only about their own absolute salaries (Frank 1984).

${ }^{6}$ In Feldstein's analysis initially $\mathrm{U}_{\mathrm{A}}=\mathrm{U}_{\mathrm{B}}$, and $\alpha=\beta$ (notation as in eq. 1 ). He finds that an increment accruing unequally between two members of a society raises social welfare.

${ }^{7}$ The presence of additional goods complicates the notation while leaving the analysis and conclusions unchanged.

${ }^{8}$ If the distribution of income is egalitarian to begin with (i.e. $U_{B}=U_{A}$ ), then social welfare is likely to increase. This follows, since in this case inequality (4) holds only if $\beta_{b} / \alpha_{a}>1$.

9 We can extend the analysis of the model in eq. (1) to $n$ individuals. We treat only the simplest case of a society with two types of individuals A and B. We assume that all type A (or type B) individuals have identical utility functions and are at identical levels of utility. If there are $\mathrm{n}_{\mathrm{A}}$ individuals of type $\mathrm{A}$ and $\mathrm{nB}$ individuals of type $B$, then the total democratic welfare function becomes $U_{T}=n_{A} U_{A}+n_{B} U_{B}$. The 
constants $\mathrm{nA}$ and $\mathrm{nB}$ are carried through the derivation, yielding a modified form of inequality (4):

$\mathrm{n}_{\mathrm{A}} \mathrm{U}_{\mathrm{A}} / \mathrm{n}_{\mathrm{B}} \mathrm{U}_{\mathrm{B}}<\beta_{\mathrm{b}} / \alpha_{\mathrm{a}}$. The larger is the number of individuals who do not partake in the benefits of growth relative to the number of individuals who do benefit, the smaller $\beta_{b} / \alpha_{a}$ can be and still allow the last inequality to be satisfied, implying a decline in welfare as a consequence of growth.

Note that similar inequalities also follow for non-democratic welfare functions if one reinterprets the coefficients $\mathrm{n}_{\mathrm{A}}$ and $\mathrm{nB}$ as the degrees to which society values the utility that accrues to persons $\mathrm{A}$ and $\mathrm{B}$. The $\mathrm{n}$ person case also follows if the coefficients are again reinterpreted as the number of individuals times the degree to which the utility of such individuals is valued. Again, if the total initial welfare of the subgroup to which the gain accrues is sufficiently small as compared with the total welfare of the subgroup not enjoying gains, the total combined welfare of the two subgroups will decrease. Thus, there exist ways to apportion additional income to a population so as to decrease its total welfare.

${ }^{10}$ We require that the indifference curves of each consumer be unaffected by the consumption of the other.

${ }^{11}$ Once again, using a democratic welfare function and assuming that the gains accrue entirely to A as an increase in $\mathrm{x}_{\mathrm{A}}$, we have

$$
\mathrm{U}_{\mathrm{T}}=\frac{\widehat{\mathrm{U}_{\mathrm{A}}}}{\widehat{\mathrm{U}_{\mathrm{B}}} \delta_{\mathrm{a}}}+\frac{\widehat{\mathrm{U}_{\mathrm{B}}}}{\widehat{\mathrm{U}_{\mathrm{A}}} \delta_{\mathrm{b}}} .
$$

and

$$
\frac{\check{Z} U_{\mathrm{T}}}{\check{Z} \mathrm{xA}_{\mathrm{A}}}=\frac{\check{\mathrm{Z} \mathrm{U}_{\mathrm{A}}}}{\breve{Z}_{\mathrm{x}}}\left(\frac{1}{{\widehat{\mathrm{U}_{\mathrm{B}}}}_{\delta_{\mathrm{a}}}}-\delta \mathrm{b} \frac{\widehat{\mathrm{U}_{\mathrm{B}}}}{\widehat{\mathrm{U}_{\mathrm{A}}} \delta^{+1}}\right) .
$$

which is negative provided $\frac{\left(\widehat{\mathbf{U}}_{\mathbf{A}}\right)^{\delta_{\mathbf{b}}+1}}{\left(\widehat{\mathbf{U}}_{\mathbf{B}}\right)^{\delta_{\mathbf{a}}+1}}<\delta_{\mathbf{b}}$. If we note that $\frac{\mathbf{U}_{\mathbf{A}}}{\mathbf{U}_{\mathbf{B}}}=\frac{\left(\widehat{\mathbf{U}}_{\mathbf{A}}\right)^{\delta_{\mathbf{b}}+1}}{\left(\widehat{\mathbf{U}}_{\mathbf{B}}\right)^{\delta_{\mathbf{a}}+1}}$ the inequality reduces to $\mathrm{U}_{\mathrm{A}} / \mathrm{U}_{\mathrm{B}}<\delta \mathrm{b}$

${ }^{12}$ In the $\mathrm{n}$ person case the outcome depends also on the number of people who benefit from the gains from growth relative to the number who do not.

13. This is the case partly because during economic growth gainers never compensate the losers whose marketable skills or investments became devalued. 
${ }^{14}$ The comparable figure for Brazil is 32 (United Nations Development, 1993, p. 17).

${ }^{15}$ In addition, envy can have an influence on the growth process itself (Cole, Maliath, and Postelwaite, 1992).

16 "If growth is less important for welfare than we have so far supposed, other goals would rise in the scale of social priorities" (Abramovitz, 1979, p. 20). 